\title{
MYSTICISM AND THE REFORMATION: A BRIEF SURVEY
}

\begin{abstract}
A number of influential theologians over the past two centuries have denied that Protestant Christianity has a place for mysticism understood as the mingling of the divine and human natures. Today a more adequate understanding of the mystical element of Christianity as a deeper awareness of God's presence in the life of believers suggests a new evaluation of the relation of Protestantism and mysticism, beginning Martin Luther, and continuing with figures like Johann Arndt, and a number of the "Spiritual Reformers," such as Andreas Karlstadt, Sebastian Franck, Valentin Weigel, as well as the theosophical Lutheran Jacob Boehme. This essay is designed to reopen the question of the relation between Protestantism and mysticism.
\end{abstract}

\section{THE DEBATE OVER PROTESTANTISM AND MYSTICISM}

The famous Protestant Church historian Adolph von Harnack (1851-1930) once summed up a familiar Protestant reaction to mysticism in his Lehrbuch der Dogmengeschichte (History of Dogma) by saying: "Mysticism as a rule is rationalism worked out in a fantastic way, and rationalism is faded mysticism." (Von Harnack 1898:271, n. 3). On this basis, he later concluded, "...a Mystic who does not become a Catholic is a dilettante." (Von Harnack 1905:99). Von Harnack's opposition between Protestantism and mysticism was rooted in the theological tradition of Albrecht Ritschl (1822-89) and his followers, and also found expression in the dialectical theology of Karl Barth (1886-1968) and Emil Brunner (1889-1966). It is still strong in some

Prof. B. McGinn, Naomi Shenstone Donnelley Professor Emeritus of Historical Theology and of the History of Christianity, Divinity School, University of Chicago; and Research Fellow, Faculty of Theology, University of the Free State, Bloemfontein, South Africa. E-mail: bmcginn@uchicago.edu 
Protestant circles today, but it is scarcely the whole story. ${ }^{1}$ For one thing, the attack on mysticism by the Ritschlians, Von Harnack, the dialectical theologians, and others can now be seen to be based on a flawed monolithic view of mysticism, or the "mystical element of Christianity," as I prefer to call it, as a non-biblical Greek notion of the mingling of God and human in "mystical union" (unio mystica). To be sure, union with Christ and God is important in Christian mysticism, as it was to Paul and John the Evangelist; but union is not the only theme in the history of mysticism, and it was rarely understood as a "mingling" of the divine and the human. This is why a number of twentieth-century Protestant theologians, beginning with Ernst Troeltsch (1865-1923) and Albert Schweitzer (1875-1965), began to take a more positive view of mysticism and its relation to all forms of Christian belief, including Protestantism. ${ }^{2}$ This is not to say that all these thinkers had the same view or evaluation of mysticism (that slippery word), but they were at least willing to entertain the view that there was no inherent contradiction between mysticism, however conceived, and Protestant Christianity. Today, many, if not most, Protestant church historians and theologians seem willing to speak about Protestant "spirituality" (long a Catholic term), and even Protestant "mysticism." But what is "Protestant mysticism," and what was the relation of the first century of Reformers (our word more than theirs) to the history of Christian mysticism? In what follows I will try to give a brief overview of this issue, both by reflecting on what the sixteenth-century religious leaders who broke with Rome inherited from the mystical tradition and how they reacted and re-shaped these mystical themes in their own thinking.

\section{WHAT IS MYSTICISM?}

Neither the term mysticus (that is, "hidden"), nor, of course, the modern word "mysticism" occur in the Bible. Nevertheless, the notion of being "in Christ" (en Christo) was central to Paul, who also spoke of being "rapt up to the third heaven" (2 Cor. 12:2-4) and even of being identified with Christ- "It is no longer I who live, but it is Christ who lives in me" (Gal. 2:20). Jesus's Last Supper Discourse in John 17 uses even stronger language about becoming one with Jesus in the unity he enjoys with his Father: "That they all may be one, as you, Father, are in me and I in you, may they also be one in us..." (Jn. 17:21). On the basis of such texts and others, often "mystically" interpreted, Christian teaching stretching back to

1 For a review of the relation between Protestantism and mysticism, see Wriedt (2003:67-87.)

2 See Troeltsch (1960 [1912]0 and Schweitzer (1931 [1930]). 
Clement of Alexandria at the end of the second century C.E. taught that the goal of spiritual practice was to attain a unifying vision, or loving union with God. Origen of Alexandria (d. 254) was the first to create a theology based on the mystical, or depth, reading of the Bible. His recognition of the inner, or mystical, dimension of Christian rituals like Baptism and the Eucharist included the possibility of attaining mystica contemplatio of God, and even union with Christ. Origen's theology was given an institutional location in monasticism in the fourth century.

Between the late fourth and the end of the fifth century C.E., various forms of mystical teaching were produced by thinkers like Evagius Ponticus, Gregory of Nyssa, and the mysterious Dionysius, who coined the term theologia mystica about 500 C.E. Mystical theology was seen not as an academic exercise, but rather a way of communal and liturgical life aimed at union with God. Though subject to many variations and later development, the notion that spiritual practices were meant to prepare for a deeper sense of God's presence, variously conceived of as seeing God, uniting with God, radical obedience to God, and even being annihilated in God, became integral to Christian spirituality, both in the East and the West, between 500 and 1500 . This is the realm that we today call "mysticism".

\section{TRADITIONS OF MYSTICISM}

Thinkers of the sixteenth and seventeenth centuries were heirs to a variety of mystical traditions from the more than twelve centuries that separated them from Origen and the first masters of mystical theology (for mysticism in the sixteenth century, see McGinn (1996:119-24)). Four traditions were of special importance. The first was the patristic mysticism of the Greek Fathers, Augustine, and Gregory the Great, which was valued by both Catholics and Protestants. The second was the monastic mysticism, best represented by Bernard of Clairvaux, and including Cistercians, Victorines, and Franciscans. This was central for Early Modern Catholic mystics, but some of these authors were also used by Protestants. The third tradition was the late medieval mysticism of Northern Europe, Germanic and Dutch. This was particularly important for the Reformers, but also read in southern Catholic lands, often in Latin translation (during the first half of the sixteenth century the Carthusian house of St. Barbara in Cologne became a center for spiritual renewal by publishing many spiritual and mystical texts, both in German and Dutch, as well as in Latin translation. Works of Henry Suso, John Tauler and Jan van Ruusbroec were translated into Latin by Laurentius Surius (1523-78), a member of the community). A fourth form was the mystical theology of Dionysius, which affected some of the medieval monastic mystics and was powerful with the northern 
mystics of the late Middle Ages. Dionysianism had an impact on a number of early modern Catholic mystics, but less so among Protestants. ${ }^{3}$

The spread of printing made all these materials more widely available than ever before. Another resource aided by the print revolution was the dissemination of mystical handbooks. These works began to be produced in manuscript form in the late thirteenth century and became popular in the fifteenth and sixteenth centuries. Some of these manuals, such as those of the Dutch Franciscan Hendrik Herp (1400-1477) and the French Benedictine Louis de Blois (1506-1566), were printed and were of moment in the later history of mysticism, although primarily among Catholics. We can also note that some forms of late medieval mysticism, especially the "Northern mysticism" of Eckhart, Suso, Tauler, and Ruusbroec lasted well into the sixteenth century, as we can see in the case of the anonymous Great Evangelical Pearl, a Dutch text written by a nun in the Eastern Netherlands in the 1530 s. $^{4}$

Another important aspect of the background to Protestant mysticism was what I have called the "New Mysticism" that began around 1200. This basic shift in the story of Western mysticism featured a number of tendencies that continued to shape sixteenth- and seventeenth-century mystical currents. ${ }^{5}$ The "New Mysticism" was democratic in the sense that its authors addressed all believers, not just a monastic elite; it was secular because it did not require retreat from the world, but could be realized in society. These authors mostly wrote in the vernacular, and therefore included women to a degree unprecedented in earlier Christianity. The "New Mysticism" advanced forms of teaching that quickly became controversial. For example, mystics such as Meister Eckhart used language that suggested that contemplatives could attain a deep union in which all distinction between the soul and God disappears, at least on some level; other mystics employed forms of excessive language about the madness of love and erotic fulfillment; they frequently spoke of extraordinary visions and raptures. Thus, some mystics, such as the French Beguine Marguerite Porete (d. 1310), were condemned as proponents of the heresy of the "Free Spirit," accused of so emphasizing their deep union with God that the mediatorial role of the church and its sacraments became unnecessary.

3 On the influence of Dionysius in general, see Coakley \& M. Stang (2009). On Dionysius among the Reformers, see Froehlich (1987:33-46).

4 The Evangelical Pearl was published by the Cologne Carthusians in a short (1535) and in a long version (1537-39, 1542). Translated into Latin (1545), French (1602), and German (1676), it was widely read among Catholics. On this last chapter in Northern mysticism, see McGinn (2012: Chapter 5) 
Underlying many of these developments was the changing relation between the liber scripturae, the Bible as the norm of belief and practice, and the liber experientiae, the inner book of the mystic's consciousness of God. Some mystics were accused of letting experience trump church teaching. Therefore, the period from the late thirteenth century on saw a growing suspicion of the dangers of mysticism. This was the situation that confronted not just the first Evangelical Reformers, but also Catholic religious thinkers at the beginning of the sixteenth century. But what did Luther and his followers, as well as Zwingli and Calvin and those we call the "Radical Reformers," make of this rich mix of traditions and tensions in late medieval religious life and thought?

\section{LUTHER AND CALVIN ON MYSTICISM}

Martin Luther (1484-1546) had a complicated relationship to mysticism. Luther's mature evangelical theology contains a number of elements marked by aspects of mystical traditions, although these appear more frequently early in his career. Works such as the First Commentary on the Psalms (Dictata super Psalterium) of 1513-15, the Commentarium on the Penitential Psalms (1518), the treatise on the Freedom of the Christian (1520), and the Commentary on the Magnificat (1521-22), all feature important mystical elements. On this basis, a number of Luther scholars over the past half-century have begun to speak of the Reformer as a mystic. Among the notable arguments for this case is Bernd Hamm's recent book, The Early Luther. Stages in a Reformation Reorientation. ${ }^{6}$ Like most issues related to the great Reformer, the question of Luther mysticus will doubtless continue to divide scholars. Luther may well have been a mystic in the sense of a believer who rooted his faith in a unique and direct inner encounter with God; but, viewed in the context of the Western mystical tradition, there are reasons for questioning the appellation of Luther as a mystical author. For one thing, Luther never wrote a mystical work in the sense of a commentary or treatise designed to guide the soul through the various practices designed to reach loving union with God. Rather, he embedded re-interpreted aspects of mysticism within the context of his new evangelical theology. Luther read the mystics selectively for the purpose of finding support for his own theology. Hence, I prefer an approach similar to that advanced by the late Heiko A. Oberman, who argued for a sic et non relationship between Luther and mysticism: one characterized by both appropriation and rejection. ${ }^{7}$ Luther's use of mysticism within his

6 See Hamm (2014). See also his more concise summary in Hamm (2007:237-87). There is a large earlier literature on Luther on mysticism that cannot be cited here.

See especially Oberman (1971:219-51). 
theology, however, allowed some of his followers in the Lutheran tradition, such as Johann Arndt and the Pietists, to draw out these aspects of his thought to create a distinctive Protestant form of mysticism.

After some early, though ambiguous, use of the Dionysian writings, Luther decisively rejected the mysticism of Dionysius by about 1519 (see Rorem (1997:291-307). For a somewhat more positive evaluation of the connection between Dionysius and Luther, see Malysz (2009:149-162)). In a famous passage from the Babylonian Captivity of the Church of 1520, speaking of Dionysius, he says: "But in his Theology, which is rightly called Mystical, of which certain very ignorant theologians make so much, he is downright dangerous, for he is more of a Platonist than a Christian. So if I had my way, no believing soul would give the least attention to these books." 8 Luther, however, never lost his respect for Augustine, Gregory the Great, Bernard, ${ }^{9}$ and some other monastic mystics. The most significant impact of mysticism on his theology, however, came from his reading of the Dominican preacher John Tauler, whom he lavishly praised. About 1516 Luther wrote marginal comments on his copy of the 1508 edition of Tauler's sermons. In introducing these Marginalia, he says, "I have found more solid and true theology in him, even though all written in the German vernacular, than is found in all the scholastic teachers of all the universities-or than could be found in their opinions." ${ }^{0}$ Luther's other major resource among the Northern European mystics of the late Middle Ages was the mystical treatise known as the Theologia Deutsch, a late fourteenth-century work which he discovered and twice edited. ${ }^{11}$ Luther was especially taken with the book, because it showed that solid German theology was not new. As he put it in the "Preface" to the second edition: "God grant this booklet will be more known, so that we will find that the German theologians are without doubt the best theologians. Amen."12 Luther's support for Tauler and the Theologia Deutsch gave these two mystics a long afterlife among Lutheran Protestants.

There are a number of important links between Luther and the mystics he favored, such as the stress on the need for inner experience of God as the foundation for true faith, and an emphasis on humility and passivity while waiting for God's justifying grace (see the Commentary on the Magnificat). Like Tauler, Luther highlighted finding God through distress and dereliction (Anfechtungen), because God remains hidden sub contrario, especially the

8 The Babylonian Captivity of the Church. Weimarer-Ausgabe (= WA) 6:562.8-14.

9 There is a large literature on Luther and Bernard; for a good survey, see Bell (1993).

10 Marginalia on Tauler's Sermons (WA 9:95.20-23). See Ozment (1970:305-11.)

11 For a survey of this work and its history, see McGinn (2005:392-404).

12 Preface to the 1518 Edition (WA 1:379.5-12). 
scandal of Christ on the cross. Like many mystics, Luther even spoke of divinization, though how important a feature of his thought this mystical theme was remains under discussion. ${ }^{13}$ Finally, Luther had a sense of union with God, a union that could be expressed in marital terms. Founded in the "happy exchange" (sacrum commercium) of the Incarnation, this union is given to believers in the sacrament of baptism and is meant to be the source for the grace of sanctification shown by living faith in God and active love of neighbor. In the Freedom of the Christian Luther used traditional language and motifs taken from the mystical tradition to describe our union with Christ through faith. "Just as the heated iron glows with fire because of the union of fire with it, so the Word imparts its qualities to the soul."14 The first power of faith is justification; the second is trust in God's promises because he is supremely truthful and righteous. Finally, "...the third incomparable benefit of faith is that it unites the soul with Christ as a bride with her bridegroom. By this mystery, as the Apostle teaches, Christ and the soul become one flesh (Eph. 5:31-32). And if they are one flesh, a true wedding is consummated between them...."15 While Luther's language here sounds like that of Bernard of Clairvaux, it is important to note that the Reformer's notion of union stresses faith as our primary attitude towards God, while Bernard presupposes faith and emphasizes ecstatic love.

John Calvin (1509-66) took a more negative view of mysticism than Luther, although he respected Augustine and Bernard. Recent work has shown that there are some affinities between Calvin's reformed theology and aspects of mystical spirituality, ${ }^{16}$ and one recent book was even entitled Calvin Mystique, ${ }^{17}$ but it would be an exaggeration, I believe, to speak of Calvin as a mystic, or even a mystical author. Nonetheless, the Genevan Reformer had a strong teaching on the union between Christ and believers, which he was even willing to call a "mystical union" (unio mystica: Institutes 3.11.10). Given Calvin's greater distance from mysticism than Luther's, it is no surprise that mysticism was more powerful in the Lutheran than in the Reformed churches.

13 The so-called Finnish School of Luther-Research has placed emphasis on the Reformer as a theologian of divinization, but only to mixed reviews among more traditional Luther-scholars. For a statement of the Finnish position, see Peura (1994).

14 The Freedom of the Christian, in Luther (2006: 2:130.25-28.) See Bernard of Clairvaux, De diligendo Dei 10.28 for this analogy (Sancti Bernardi Opera 3:143.17-18).

15 The Freedom of the Christian, in Luther (2006: 134.14-18).

16 See Canliss (2010) and Tamburello (1994).

17 See Keller (2001). 


\section{SOME PROTESTANT MYSTICS}

If one were pressed to name one Protestant mystic, probably the name of the Lutheran pastor Johann Arndt (1555-1621) would be most often put forward. In reaction to the Scholastic rigidity of much contemporary Lutheran dogmatic theology, Arndt returned to Luther's emphasis on the experience of faith and his use of mystical texts to create a teaching that insisted that Evangelical faith had to center on the path to spiritual perfection. Arndt's True Christianity, originally published in four books (1606-10), had an immense success for centuries (After Arndt's death, the original four books of True Christianity were often combined with two of his later treatises to form a six-book compendium. See Geyer (2001). The other major recent work on Arndt is that of Braw (1986)). True Christianity is a summary of the Christian life, one that argues that the justifying faith central to the Reformation is nothing without the process of sanctification that aims at loving union with God. In the "Preface" to True Christianity Arndt (1753:40) puts it this way: "It is not enough to know God's word; one must also practice it in a living, active manner." In setting forth this teaching, Arndt often turned to medieval mystics, not only Bernard and the masters of Northern mysticism used by Luther, but also books like the De imitatione Christi and figures like Angela of Foligno that Luther had not employed. Arndt (1753:554) even says that he structured the first three books of True Christianity according to the traditional three stages of mystical progress, "...beginning in repentance," after which "follows middle age, more illumination through the contemplation of divine things..., finally to reach "...the perfection of old age, which consists in full union through love, which St. Paul called the perfect age of Christ and the perfect man in Christ" (Eph. 4:13). Arndt emphasized mystical themes far more than Luther, especially the birth of God in the soul, the necessity for "releasement" (Gelassenheit), deification, and a marital union with God that could be described in the erotic language of the Song of Songs (True Christianity, especially Books III and V). Arndt was a controversial figure. Lucas Osiander (1571-1638) attacked him as an "Enthusiast" and cryptopapist, who was not teaching "Christianity" (Christentum), but "Tauleranity" (Taulerdom). Nevertheless, Arndt was among the most widely read Lutheran authors and was influential on the birth of German Pietism towards the end of the seventeenth century.

The Radical Reformation is a convenient term to identify the individuals and groups who became convinced that Luther, Calvin, and their followers had not gone far enough in their rejection of the medieval church and in the establishment of pure religion based on the inner action of the Holy 
Spirit. ${ }^{18}$ Many of the Radicals were biblical literalists, like the Anabaptists. Others, however, can be described as Spiritualists, thinkers who so stressed the experience of the Spirit within that the external aspects of religion (Bible, visible church, sacraments, etc.) became secondary, even dispensable. In their emphasis on interiorization the Radicals often appealed to the Northern mystics, such as Tauler, the Theologia Deutsch, even Eckhart, but there is a real difference between the interiorization of these medieval figures who never rejected the externals of Catholic religion and the Radicals who did, though in differing ways. ${ }^{19} \mathrm{~A}$ brief look at three of the Radicals will provide a sense of the mysticism of this wing of the Reformation: Andreas Karlstadt (1486-1541), Sebastian Franck (1499-1542), and Valentin Weigel (1533-1588).

Karlstadt was a colleague of Luther, who broke with him between 1520 and $\mathbf{1 5 2 5}$ over many issues, not least the authority of the Holy Spirit in determining belief and practice. ${ }^{20}$ Like Luther, he was influenced by Tauler and the Theologia Deutsch, but he went further than Luther in the two treatises he wrote on Gelassenheit $(1520,1523)$ in the way he emphasized the letting go of self and other teachings of the Northern mystics. Karlstadt's view of releasement implies a mystical anthropology based on the soul's ground in God (something far from Luther), as well as a deeper sense of union than Luther would have countenanced. For example, in his 1523 treatise Letting Go of Self, and What the Word Releasement Means, and Where It is Found in Scripture, he foregrounds gelassenheit as the fundamental Christian practice in language remarkably close to that of Eckhart and his followers:

Everything to which 'l' and 'I-ness' (icheit), 'me' and 'myself,' may cling must leave me and fall off, if I am to be released. For releasement penetrates and flows through every created thing and comes into its uncreated Nothingness (ungeschafenen nichts)-where it is uncreated and has no being, that is, its Origin and Creator. ${ }^{21}$

Similar emphasis on mystical releasement and a high anthropology is found in a number of the later Spiritualists. Thinkers like Sebastian Franck cared little about external religious practices, even the sacraments, in their pursuit of returning to our pre-established unity in God. The learned

18 A classic work on the topic, first published in 1961, is Williams (1992), More up-to-date is Rother \& Stayer (2007).

19 On the relation of the Radicals to Northern mysticism, see Ozment (1973).

20 For an introduction, see Sider (1974). There is an anthology of his works: Furcha (1995).

21 My translation from the German text given in the notes of Sider (1974:213, 229-30). 
Franck used a wide variety of mystical sources to present his view of the paradoxes of true spiritual religion in the summa he called the Paradoxa of 1534. Franck's teaching on the supremacy of interiority is well captured in this passage from Nos. $279-80$ of the Paradoxa:

The Word became flesh that it may, though hidden in itself, be revealed to us. The Word cannot be shouted into us from outside, but must be found, taught, and perceived within us, stimulated, driven and taught by the Holy Spirit. It cannot be spoken or written, for it is God's Word. ${ }^{22}$

Therefore, the real New Testament is the Holy Spirit within us, because “...properly speaking, no book or external word and worship is of the New Testament."23

The most important of the Spiritualist mystics was Valentin Weigel, who concealed his true views while serving as a Lutheran pastor for many years (on Weigel, see Weeks (2000), as well as the anthology by Weeks (2003)). In the midst of religious doubts occasioned by the intra-Lutheran disputes of his youth Weigel was rescued by a revelation from God that gave him an inner book as the source of his mystical teaching. In Chapter 24 of his major work, The Golden Grasp (Der güldene Griff), he recounts how these quarrels and controversies left his heart more and more uncertain, so that he called out to the Lord. He continues:

...grace was visited to me from above, for a book was shown to me that delighted me and illuminated my heart, so that I could judge and know all things [and I] could see more clearly than if all the teachers in the world had instructed me with their books. For from it all books had been written since the beginning of the world, and this book is in me and in all human beings,...but few indeed could read it. ${ }^{24}$

Weigel's early works (1570-71) are based on Eckhart, Tauler, and the Theologia Deutsch. His reading of the Lutheran doctrine of justification through a mystical lens stressing Gelassenheit, divine birth, and union and deification was expanded upon in his mature pansophical writings, especially The Place of the World (1576) and The Golden Grasp (1578).

22 Franck's Paradoxa ducenta octoginta were first published in 1534. I cite from the English version by Furcha (1986:486-87).

23 Paradoxa Nos. 83-85 (Furcha 1986:138).

24 The text is in Weigel (1996-: Vol 8: 89-91) For a translation, see Weeks (2000:205-6). 


\section{JACOB BOEHME}

In the history of Western mysticism, the Görlitz cobbler and auto-didact, Jacob Boehme (1575-1624), has always been a controversial figure. ${ }^{25}$ In a brief period of time Boehme produced a succession of dense and original works setting forth a theosophy, or hidden wisdom, about God, the Divine Virgin Sophia, creation and its evolutionary stages, Christ, and redemption. Although he lived as a Lutheran layman, Boehme was attacked as a heretic during his lifetime and afterward. He really stands closer to the Radicals than he does to a Lutheran mystic like Arndt. Boehme has attracted fervent disciples, who see him as a major thinker, even the originator of modern speculative thought, as well as skeptics, who, in the words of John Wesley in 1742, dismiss his writings as "...the most sublime nonsense; inimitable bombast; fustian not to be paralleled" (Wesley 1990:272). His most popular work is the early Aurora of 1612; his later works, such as the massive commentary on Genesis, the Mysterium Magnum, written between 1622 and 1624, are more interesting from the perspective of mysticism. At the end of his life Boehme also wrote a series of tracts of a more Christological character published as The Way to Christ. ${ }^{26}$ In Boehme the esoteric tendencies among the Spiritualist Reformers that had begun to challenge traditional doctrine found their ultimate evolution. The question of how far Boehme should be considered a Christian mystic is still under dispute; but there can be no doubt that he was one of the greatest theosophical thinkers in the Western tradition.

\section{THE ENGLISH REFORMATION}

One chapter in the story of Protestant mysticism that does not easily fit within the Continental perspective I have been sketching is that of the mystical aspects of the English Reformation. A number of Anglican poets from the seventeenth century have been described as mystical in orientation, notably George Herbert (1593-1633), Henry Vaughan (1622- 1695), and Thomas Traherne (ca. 1637-1666). ${ }^{27}$ Even more complex is the evaluation of the poetry and prose of John Donne (1571-1631)—Is Donne's magnificent religious poetry mystical, and, if so, in what sense? It is also important to note that there is a group of prose works of a mystical character from seventeenth-century England, coming, perhaps unexpectedly, from the more radical side of the English Reformation, the Puritans, who rejected the Elizabethan compromise

25 Weeks (1991). On his mysticism, see Walsh (1983) and O'Regan (2002)..

26 There is an English translation by Erb (1978).

27 Considerable literature has been devoted to the relation between mysticism and seventeenth-century English poetry; see, e.g., Itrat-Husain (1948), Martz (1954) and Schwartz (2008). 
between Catholic and Protestant elements in the English Church. ${ }^{28} \mathrm{~A}$ number of Puritans, such as John Everard (ca. 1575-1640), Francis Rous (1579-1659), Henry Vane (1613-62), and Edward Polhill (1622-94), had an interest in medieval mystical texts, which they translated, as well as in writing their own mystical treatises. ${ }^{29}$ Finally, the Quaker tradition of English mystical religion was reminiscent of the Radical Spiritualists. Under the leadership of George Fox (1624-1691), who began to receive revelations in 1646, the Quakers preached a message of reliance on the inner light of the Holy Spirit and abandonment of the exterior practices of the church. The Journal that Fox dictated in 1673-75 while in prison is a striking account of visionary illumination. ${ }^{30}$

\section{CONCLUSION}

In conclusion, even this brief survey shows that the balance sheet of Protestant mysticism of the sixteenth and the first part of the seventeenth century is impressive. While the mystical element in Christianity did not play as large a role in the Protestant confessions and groups as it did in Counter-Reformation Catholicism, the Reformers and their heirs did not reject mysticism, as Ritschl, Von Harnack, and others once argued. The Reformers, though in different ways, sought to come to terms with the rich traditions of Christian mysticism, adopting some aspects, rejecting others, and more often effecting transformations in what they had inherited. Viewed in the light of the spirituality and mysticism of the patristic and medieval heritage they inherited, we can begin to get a better sense of the distinctive character of Protestant mysticism.

Modern historians are often eager to identify "turning points," or decisive events that brought us to where we are today (as if this is always a good thing). The Reformation Era generally is seen as such an historical shift, though its significance remains under dispute, and will doubtless continue to provoke study and disagreement. In the history of mysticism, I would describe the sixteenth and seventeenth centuries as a time of transition between eras, but one still largely rooted in the past. In any case, a look at the Reformers underlines, once again, the significance of the adage put forth by the great French scholar of Early Modern French mysticism, Henri Brémond (1930: 2:432), who said: "It is not possible to ignore the mystics without disowning one's self."

28 On the relation of Puritanism to mysticism, see Wakefield (1957), Nuttall (1975:518-31) and Brauer (1987:39-58).

29 Representative of these efforts were Rous's The mysticall marriage (1635) and Polhill's Christus in Corde (1680).

30 For an introduction to Quaker spirituality and mysticism, see Birkel (2004). 


\section{BIBLIOGRAPHY}

ARNDT, J.

1753. Wahres Christentum. Vorrede 1. Tübingen: Schramm.

BELL, T.

1993. Divus Bernhardus. Bernhard von Clairvaux in Martin Luthers Schriften. Mainz: Philipp von Zabern.

BIRKEL, M.L.

2004. Silence and witness. The Quaker tradition. Maryknoll: Orbis Books.

BRAUER, J.C.

1987. Types of puritan piety. Church History 56:39-58.

Braw, C.

1986. Bücher im Staube. Die Theologie Johann Arndts in ihrem Verhältnis zur Mystik. Leiden: Brill.

BRÉMOND, H.

1930. A literary history of religious thought in France. London: SPCK.

CAnLiss, J.

2010. Calvin's ladder. A spiritual theology of ascent and ascension. Grand Rapids: Eerdmans.

Coakley, S. \& Stang, C.M. Eds.

2009. Rethinking Dionysius the Areopagite. Oxford: Wiley-Blackwell.

ERB, P.

1978, Jacob Boehme. The way to Christ. New York: Paulist Press.

Froehlich, K.

1987. Pseudo-Dionysius and the reformers of the sixteenth Century. In: Pseudo-Dionysius. The complete works. Translated by Colm Luibheid (New York: Paulist Press), pp. 33-46.

FURCHA, E.J.

1986. Sebastian Franck. 280 paradoxes or wondrous sayings. Lewiston/ Queenstown: Edward Mellen.

1995. The essential Carlstadt. Scottdale, PA: Herald Press.

GeYer, $\mathrm{H}$.

2001. Verborgene Weisheit. Johann Arndts "Vier Bücher vom Wahren Christentum". 3 vols. Berlin: Walter de Gruyter.

HАMM, B.

2007. Wie mystisch war die Glaube Luthers? In: B. Hamm \& Volker Leppin (eds.), Gottes Nähe unmittelbar Erfahren (Tübingen: Mohr Siebeck, 2007), pp. 237-87.

2014. The early Luther. Stages in a Reformation reorientation. Grand Rapids: Eerdmans. (German original 2012). 
ItRAT-Husain, M.A.

1948. The mystical element in the metaphysical poets of the seventeenth century. London: Oliver and Boyd.

KeLler, C.A.

2001. Calvin Mystique. Au couer de la pensée du Réformateur. Geneva: Éditions Labor et Fides.

LUTHER, M.

2006. Lateinisch-Deutsche Studienausgabe. 2. Christusglaube und

Rechtfertigung. Edited by J. Schilling. Leipzig: Evangelische Verlaganstalt.

Malysz, P.J.

2009. Luther and Dionysius: Beyond mere negations. In: S. Coakley \& C.M. Stang (eds.), Rethinking Dionysius the Areopagite (Oxford: Wiley-Blackwell), pp. 149-62.

MARTZ, L.L.

2008. The poetry of meditation. A study of English religious literature of the seventeenth century. New Haven: Yale.

McGinN, B.

1996. Mysticism. In: H.J. Hillerbrand (ed.), The Oxford encyclopedia of the Reformation, 3 vols. (Oxford: Oxford University Press, 1996), Vol. 3, pp. 119-24.

1998. The flowering of mysticism. Men and women in the new mysticism 1200-1350. New York: Crossroad-Herder.

2005. The harvest of mysticism in Medieval Germany (1300-1500). New York: Crossroad.

2012. The varieties of vernacular mysticism 1350-1550. New York:

Crossroad-Herder.

Nuttall, G.

1975. Puritan and Quaker mysticism. Theology 78:518-31.

O'Regan, C.

2002. Gnostic apocalypse. Jacob Boehme's haunted narrative. Albany: SUNY Press.

Oberman, H.O.

1971. Simul gemitus et raptus: Luther and mysticism. In: S.E. Ozment (ed.), The Reformation in medieval perspective. Chicago: Quadrangle Books.

OZMENT, S.E.

1973. Mysticism and dissent. Religious ideology and social protest in the sixteenth century. New Haven: Yale University Press.

1979. An aid to Luther's marginal comments on Johannes Tauler's sermons. Harvard Theological Review 63:305-11.

Peura, Simo.

1994. Mehr als Mensch: Die Vergöttlichung als Thema der Theologie Martin Luther von 1513 bis 1519. Mainz: Institut für Europäische Geschichte. 
PolHILL, E.

1680. Christus in corde, or, the mystical union between Christ and believers considered in its resemblances, bonds, seals, priviledges and marks. London: Cockerill.

RoRem, P. 1997. Martin Luther's Christocentric critique of Pseudo-Dionysian spirituality. Lutheran Quarterly 11:291-307.

RotheR, J.D. \& STAYER, J.M. Eds. 2007. A companion to Anabaptism and Spiritualism, 1521-1700. Leiden: Brill.

Rous, $\mathrm{F}$. 1631. The mysticall marriage: Experimentall discoveries of the heavenly marriage betweene a soule and her saviour. London: William lones.

SCHWARTZ, R.M. 2008. Sacramental poetics at the dawn of secularism. Stanford: Stanford University Press.

SCHWEITZER, A.

1931 [1930]. The mysticism of Paul the Apostle. London: A. and C. Black.

SIDER, R.J.

1974. Andreas Bodenstein von Karlstadt. The development of his thought 1517- 1525. Leiden: Brill.

TAMBURELLO, D.A.

1994. Union with Christ. John Calvin and the mysticism of St. Bernard. Louisville: Westminster John Knox.

Troeltsch, E. 1960 [1912]. The social teaching of the Christian churches. 2 vols. New York: Harper and Row.

Von HaRnack, A.

1898. History of Dogma. Volume 3. Translated from the third German edition by Neil Buchanan. London: William and Norgate.

1905. History of Dogma. Volume 1. Translated from the third German edition by Neil Buchanan. London: William and Norgate.

WAKEFIELD, G.S.

1957. Puritan devotion: Its place in the development of Christian piety. London: The Epworth Press.

WALSH, D.

1983. The mysticism of innerworldly fulfillment. A study of Jacob Boehme. Gainesville: University of Florida Press. 
WEEKS, W.

1991. Boehme: An intellectual biography of the seventeenth-century philosopher and mystic. Albany: SUNY Press.

2000. Valentin Weigel (1533-1588). German religious dissenter, speculative theorist, and advocate of tolerance. Albany: SUNY.

2003. Valentin Weigel. Selected spiritual writings. New York: Paulist Press.

WeIGEL, V.

1996. Valentin Weigel-Sämtliche Schriften. Edited by Horst Pfefferl. 15 vols. Stuttgart-Bad Canstatt: frommann-holzboog.

WESLEY, J.

1990. The works of John Wesley. Vol. 19. Journals and papers II (1738-43). Edited by W. R. Ward \& R. P. Heitzenrater. Nashville: Abingdon.

Williams, G.H.

1992. The Radical Reformation. Ann Arbor: Edwards Brothers. $3^{\text {rd }}$ ed.

WRIEDT, M.

2003. Mystik. Religion der Zukunft-Zukunft der Religion? Leizig:

Evangelische Verlaganstalt.

Keywords

Mysticism

Mystical theology

Union with Christ
Sleutelwoorde

Mistiek

Mistiese Teologie

Eenheid met Christus 